\title{
Student's Response in Online Learning Process: A Case Study of English Education Students
}

\author{
Rizqi Husaini, M.Pd. \\ Universitas PGRI Madiun; Jln. Setiabudi No. 85 Madiun, Tlp.(0351) 459400 \\ E-mail: rizqihusaini02@gmail.com
}

\begin{tabular}{|c|c|}
\hline \multicolumn{2}{|l|}{ Keywords: } \\
\hline Online Learning, & Students' \\
\hline Activeness, & Students' \\
\hline $\begin{array}{l}\text { Motivation, Students } \\
\text { Students' Confidence }\end{array}$ & 'Literacy, \\
\hline
\end{tabular}

Keywords:

Online Learning, Students,

Motivation, Students' Literacy,

Students' Confidence

\begin{abstract}
A B S T R A C T
The purpose of this study was to look at the level of students' activity in online lecturing. The method that used on this research was descriptive qualitative research. In this research, the data source was the record of online lecturing one of the colleges in Madiun contained in the online media platform used by the author. The research results found that the level of activity of students in the discussion is excellent compared with offline lectures. Several things that can affect it, such as the level of student confidence, comfort in attending lectures, and enough time to read the material provided can be longer so that they can understand the material. So it can be concluded that online lectures can increase students' response.
\end{abstract}

\section{INTRODUCTION}

In 2020, the year that will not be forgotten by the world community. A virus, which does not know where it came from, shocking throughout the world. The virus gives the name covid-19. It is a virus that has changed the whole world order. According to reports from the World Health Organization (2020), there were more than 10 million people have infected with more than 500 thousand deaths in the world.

As a vast country with the fourth largest population in the world, Indonesia is also inseparable from this virus attack. According to the Indonesian Ministry of Health, more than 50 thousand positive cases have confirmed with more than 3 thousand deaths. Of course, this indirectly affects all aspects of Indonesian people's lives. It is starting from the economic sector, tourism, social, cultural, and education.

From the education sector, almost no education levels allow students to enter school or campus. All levels of education, like it, not, ready, or not ready, must implement online learning so that the scheduled education program can be completed on time even though several things are still inhibiting the learning process. Starting from the human resources that are not ready, online facilities such as laptops, cellphones, and the internet are inadequate due to infrastructure limitations arise during the online learning process.

Online learning, or we can call as E-learning, it is not new. This concept has long existed and used by most of the world-renowned schools or colleges. E-learning, according to Abou ElSeoud et al. (2014), is a concept of learning that used a web that is connected using the internet or intranet to connect teachers and students. Here is the use of the network and the internet as a link between teachers and students. In this case, the system can be likened to a class where there are materials, discussion sites, and all matters relating to learning. At the same time, the internet or intranet, as a network, used to display the web to teachers and students.

As technology develops, online learning not only displays a piece of writing but can also have face-to-face meetings even though it is not physically meeting. It then causing confusion 
about the definition of online learning. Nguyen, (2015) said that if the education was using the internet network, both web-based concepts or face-to-face meetings, by utilizing existing technology then it can be said as online learning.

The application of electronic learning in Indonesia is still minimal. (Priyanto, 2009) on his research in Yogyakarta found that the used of e-learning was still not optimal. There is lot of factor that affect it, such as the technology resources, human resources, environment, learning strategies, and funding availability. As expressed by Anza, Luthfi, \& Arfah (2019), in their research at one of the schools that had implemented electronic learning, they found that it was still not optimal. There are some fundamental problems that occurred, such as school is not aware about e-learning, do not design good learning approach, do not give any training, gap in IT savviness in teacher and academic staffs. Moreover, by implementing e-learning, learning can be done anytime, anywhere, and in any condition. Furthermore, learning materials can be accessed by anyone, both teachers and other school students, and all stakeholders, hoping that this learning model can continue to develop. (Clover, 2017)

Talking about learning is inseparable from the performance of students in the class, such as cognitive, affective, and psychomotor. Bloom (1956) in Kasenda, Sentinuwo, \& Tulenan (2016) explained that aspects of learning must not separate from the three points inherent in a child's self, namely the realm of thought processes, values or attitudes, and skills came to be known by the three aspects above. It can be concluded that the use of any learning, particularly online learning, still has to pay attention to three issues.

Haryadi \& Aripin (2015) said that children could not be said to be intact humans if they do not have affective and psychomotor intelligence despite having comprehensive capabilities in the cognitive field. It can be explained that, in the concept of online learning, although they cannot face-to-face between teachers and students, they must still pay attention to the affective and psychomotor domains. So students are not only able to think cognitively but have the right attitude and skill values.

In this study, researchers focused on the affective domain of students in participating in online learning compared to offline learning. Offline learning or face-to face learning is traditional professional learning approach that provides an interaction and closeness relationship between teacher and learners.(Sankar \& S. Sankar, 2010). Harsanto (2007) explained that five aspects are included in the affective domain: acceptance, response, living values, organizing, and characterization. In this case, more focused on student responses. This is because the response of students in learning has always been a problem in the learning process. Harsanto (2007), in the realm of student response, is described as the active role of students in learning activities, both in terms of questions and answers and discussion. Talking about student responses in learning might be said to be a bit less interesting to discuss. However, from observations during the implementation of online learning, the writer found interesting things about students' responses in learning.

As in general, before online learning began to be implemented, of course, most still implemented face-to-face meetings in the classroom. As in general, in learning in the classroom, students' condition will be diverse, ranging from those who are active in responding to the teacher or lecturer there are very passive in teaching and learning activities. In their research, Al-Mahrooqi, Denman, \& Al-Hasani (2017) found that much influence why students can be very passive in class, including communication and classroom environment.

The first relates to communication. In the teaching and learning process, of course, communication is essential in the interaction between teachers and students. The use of 
language is essential in teaching and learning activities. As a source of knowledge, the teacher needs to use language that is easily understood by students. According to Prozesky (2000), the way to communicate teachers is not only in the form of speech but also in writing. It means that the language used by the teacher is either spoken or written in learning material, even though the source of the material used is tough to understand, as much as students must understand possible.

The second is related to the classroom environment. The classroom environment's condition indirectly also dramatically affects the level of student activity in responding to the learning process. Singh (2014) said that the classroom environment is very influential in the learning process. Talking about the environment not only talks physically but also everything in the school environment from the teacher to the bonds of friendship. Although trivial, indirectly, this affects how students respond in the learning process.

Based on the explanation above, on this research the researchers are interested in examining students' responses to online learning. The extent to which student responses to online learning are used. Second, what factors influence this can happen. Lastly, whether it will also affect students' understanding of the material presented. This is important because it can be used as an evaluation of the deficiencies that exist in online learning. So that this type of learning can continue to be used and run well and correctly.

\section{METHOD}

In this study, it was using qualitative research methods with a case study design. According to Ary, Jacobs, \& Razavieh (2010), a case study focuses on an individual, a group, an organization, and a phenomenon that aims to obtain detailed information in a case. The case that arises is a change in student activity, from previously passive to more active. When previously offline learning, students did not really respond to what was explained by the lecturer or teacher. However, in online learning, they really respond to what is given by the teacher or lecturer. whether this is related to the implementation of online learning or not.. In research requires a sample to be studied. The sample is something that is used as a representation of a study and as a form of generalizing a research result (Flick, 2009). In this study, the sample is college students of on university in Madiun. They are 6th semester students with 20 students. The data taken is the result of online learning in the form of discussions on online learning applications. As well as the results of closed interviews for several students who had changes in behavior from previously passive to active discussions.

\section{RESULTS AND DISCUSSION}

This research was conducted for one semester in the Translation and ESP courses. From the results of observations on student discussion activities, it was found that almost all students participated in the discussion. Besides that, the content of the discussion was also varied, whether it was just asking questions or expressing their opinions on the discussion. Besides that, there were some students when they were in class who looked very quiet and never expressed their opinions, when discussions on the online learning platform were active in discussions and the material was delivered in accordance with what was being discussed. However, apart from that some students look alike. So that there is no difference or change in attitude or activity.

This was then followed by a short interview with several students who showed changes in their learning activities. There are several questions asked. First, regarding what distinguishes offline and online learning, almost all answered that they were required to be more active 
because they had to participate in discussions. Besides that, they mentioned that with online learning they could also study the material previously provided earlier.

Then the second question about the level of mastery of the material given. Students' answers are quite diverse. Some students can master the same material as when learning offline. Some students are a little confused with the material given. Some do not even understand at all. Then asked how they overcome this. Most of them answered by asking the lecturers through the provided discussion forums.

The next question about why when learning offline they rarely or never ask or respond to discussions given by the lecturer or teacher. Most of them answered that they were less confident when they asked questions or argued. They are afraid of being laughed at by their friends because they cannot master the material well. Then they were also asked why they actively asked questions and had opinions during online learning. There are various answers given by students. First, because they do not understand the material given. Second, because it relates to their attendance in class. Third, with writing they can more easily express their opinions when discussing than in spoken language.

From several observations and brief interviews mentioned above. Then it will be explained further about their responses related to several things, including about their activeness and related understanding of their material.

\subsection{Students' Response Related to Students' Activeness}

As outlined in the introduction, student activity in the teaching and learning process is part of the affective domain of student responses. Student responses and this can be explained in conditions when students actively interact, discuss, and ask questions in online learning media that used. Then the question arises, why can this be interesting?

During the discussion process, some things are exciting to be observed further. Again, this will be compared to the offline learning process. In the offline learning process or the classroom, some students can be said to be very passive in the sense that some of these students are very rare or even never respond to interactions with lecturers. It might be caused by several things that have been mentioned in the explanation above.

When learning online, students look very active. This can be seen from their active participation in the discussion. Besides that, they are also actively asking about material, which is difficult for them to understand. This was not seen during offline learning activities at 2-4 meetings before online learning was carried out. When lecturers ask questions, they appear not confident to answer or express their opinions.

\subsection{Students' Response Related to Students' Knowledge}

The first part has been described related to findings of student responses to online learning activities related to students' activeness. This section will be explained the other side of student responses in participating in teaching and learning activities. It is about the knowledge of students while participating in discussion activities in online learning media.

Previously, when learning offline, there are some students were very passive in the classroom. The results of several observation times when following the discussion in the classroom and when there is an assignment of lecturers indicate that the student is less material being discussed. It can be seen from the duration of work assignments, when some students can do on time, other students sometimes take longer time. Secondly, from direct observation during the teaching and learning process, the student seemed to lack understanding, but on the one hand, they did not dare to ask the lecturer.

When online learning began, there was something interesting to observe. Some students previously had difficulty understanding the material, but when they took part in discussions on 
online learning, they were able to follow it properly. This can be seen from the opinions given when participating in the discussion; it seems that they can follow the discussion well. In addition, the questions asked can be said to be questions that are not just a formality of asking.

\subsection{Factors Affecting}

From the results of observations and short interviews above, there are several factors that can cause this, including:

\subsubsection{Students' Confidence}

The first thing is the level of student confidence. When offline learning, students tend to lack confidence in responding to interactions with teachers or lecturers. They are afraid of being ridiculed if statements or statements that are expressed are false or do not match the material provided. It has been a problem of education in Indonesia, even though the levels may vary. (Nurhayati, Rosmaiyadi, \& Buyung, 2017) on their research in one school in Yogyakarta the result of interview of some students have less confidence.

However, when online learning, there are changes in students. It can be seen from the record of the discussion. They are more willing to ask questions and discuss them. It is because they did not meet directly with other students. Therefore, they feel comfortable asking questions and questions. It will be related to the second point in this discussion.

Students' confidence is crucial in the teaching and learning process. It is because, indirectly, affects everything in students, such as cognitive, affective, and students' psychomotor. Therefore teachers need to create a conducive situation in learning. As stated by Ziemba (2007), as much as possible, the teacher creates a conducive learning space so that students can participate in the teaching and learning process. In the end, those who were previously less active can be more active in responding to interactions both with the teacher and with other students. According to him, students need to be given responsibility so that they will have reasonable confidence slowly. Parachin (2003) state that "Here are seven key steps for developing dynamic self-confidence

1. Begin with the 'As-If Principle,'

2. Accept responsibility,

3. Do not let what you speak make you weak,

4. Take the dare,

5. Reject contrary advice,

6. Follow the positive voices, and

7. Make anxiety, your ally.

\subsubsection{Students' Literacy}

Second, about student literacy. As it is common knowledge, the level of literacy in the current generation tends to be low, especially in Indonesia. International Student Assessment (PISA) in 2019 showed that Indonesian students' literacy culture ranks 72th of the students from 76 participating countries.(Kasih, 2020). It is also related to students' responses in the learning process. In offline learning, they tend to be passive because of their limited knowledge. Even though they know the material to be learned at a meeting, there is no desire to learn in advance about the material. Most of them only learn and read the material when the teacher or lecturer has opened the material to be taught.

Before the discussion begins in online learning, the teacher or lecturer gives the material to be discussed. They are given half to one hour to read the material. Only after that will they start discussing. In the discussion, they start to ask or discuss. Discussion 
activities become livelier because they have basic knowledge by reading the material beforehand. It proves that literacy, in this case, also affects the response of students in the learning process. Although a little forced them to read, at least they want to read the material first. It will also be related to the third point of this discussion.

Ratri (2015) stated that home parental involvement, students' perceptions of reading, reading outside school, and information and communications technology [ICT] use) influenced reading literacy. Thus, special handling is needed so that their level of willingness and ability to read can be increased even more so if it arises from their desires without coercion from others.

\subsubsection{Students' Motivation}

Third, about motivation. As is widely explained in any educational theory, there must be a motivation in the process. Motivation, in offline learning, is undoubtedly different from online learning. Motivation can be said to be a lubricant in the engine or the fuel to run the engine. When the engine runs out of lubricant or fuel it will cause the engine to malfunction or stop running. The same as motivation in learning, when students have lost motivation, the learning process will stop. (Vibulphol, 2016)

In online learning, they also need motivation to learn. From the results of the observations above, it can be seen that many things affect their motivation in participating in online learning. First, about class attendance. Many lecturers make discussion forums in online learning to see who is taking classes and who is absent from attending classes. Second, about student grades. Several lecturers use this as part of assessing student performance. Third, about knowledge. With the discussion, they indirectly increase knowledge. They learn to argue without anyone directly bothering them.

\section{CONCLUSION}

From some of the explanations above, that online learning can be effective in helping improve student response in following learning. This is because several supporting factors exist including student confidence, student literacy, and student motivation. Besides this, it also indirectly affects the level of students' understanding of the material. However, to determine whether this will also affect their achievement or not, further, research that is more comprehensive remains to be done.

\section{REFERENCES}

Abou El-Seoud, S., Seddiek, N., Taj-Eddin, I., Ghenghesh, P., Nosseir, A., \& El-Khouly, M. (2014). E-Learning and Students' Motivation: A Research Study on the Effect of ELearning on Higher Education. International Journal of Emerging Technologies in Learning (IJET), 9(4), 20. https://doi.org/10.3991/ijet.v9i4.3465

Al-Mahrooqi, R., Denman, C. J., \& Al-Hasani, F. (2017). A student perspective on the use of motivational strategies by their english language literature instructors in an omani university. Language and Culture, (9), 85-103. https://doi.org/10.17223/24109266/9/11

Anza, F., Luthfi, A., \& Arfah, S. (2019). Introduction e-learning in educational sector case study Senior High School in DKI Jakarta. ASEAN Journal of Community Engagement, 3(1), 139-162. https://doi.org/10.7454/ajce.v3i1.149 
Ary, D., Jacobs, L. C., \& Razavieh, A. (2010). Introduction to research in education (8th ed). Belmont, CA: Wadsworth.

Clover, I. (2017, February 17). Advantages and Disadvantages of E-Learning Technique. Retrieved July 18, 2020, from Elearningindustry website: Https://Elearningindustry.Com/Advantages-And-Disadvantages-Of-Elearning

Flick, U. (2009). An introduction to qualitative research (4th ed). Los Angeles: Sage Publications.

Harsanto, R. (2007). Pengelolaan Kelas Yang Dinamis: Paradigma Baru Pembelajaran Menuju Kompetensi Siswa. Yogyakarta: Kanisius.

Haryadi, T., \& Aripin, A. (2015). Melatih Kecerdasan Kognitif, Afektif, dan Psikomotorik Anak Sekolah Dasar Melalui Perancangan Game Simulasi "Warungku." ANDHARUPA: Jurnal Desain Komunikasi Visual \& Multimedia, 1(02), 122-133. https://doi.org/10.33633/andharupa.v1i02.963

Kasenda, L. M., Sentinuwo, S., \& Tulenan, V. (2016). Sistem Monitoring Kognitif, Afektif dan Psikomotorik Siswa Berbasis Android. Jurnal Teknik Informatika, 9(1). https://doi.org/10.35793/jti.9.1.2016.14808

Kasih, A. P. (2020, April 5). Nilai PISA Siswa Indonesia Rendah, Nadiem Siapkan 5 Strategi Ini [News]. Retrieved September 24, 2020, from Kompas.com website: https://edukasi.kompas.com/read/2020/04/05/154418571/nilai-pisa-siswa-indonesiarendah-nadiem-siapkan-5-strategi-ini?page $=$ all

Nguyen, T. (2015). The Effectiveness of Online Learning: Beyond No Significant Difference and Future Horizons. 11(2), 12.

Nurhayati, N., Rosmaiyadi, R., \& Buyung, B. (2017). Efforts To Improve Student's Self Confidence Using Collaborative Learning Model. JPMI (Jurnal Pendidikan Matematika Indonesia), 2(2), 57. https://doi.org/10.26737/jpmi.v2i2.223

Parachin, V. M. (2003). Developing Dynamic Self-Confidence. Super Vision, 64, 13-15.

Priyanto, M. (2009). REDESIGN OF E-LEARNING DEVELOPMENT IN INDONESIA. 11.

Prozesky, D. R. (2000). Communication and Effective Teaching. Community Eye Health, 13(44), 5.

Ratri, S. Y. (2015). Student factor influencing Indonesian student reading literacy. JOURNAL OF EDUCATION, 8(1), 9.

Sankar, L., \& S. Sankar, C. (2010). Comparing the Effectiveness of Face-to-Face and Online Training on Teacher Knowledge and Confidence. 667-691. https://doi.org/10.28945/1282

Singh, A. (2014). Conducive Classroom Environment in Schools. 3(1), 6.

Vibulphol, J. (2016). Students' Motivation and Learning and Teachers' Motivational Strategies in English Classrooms in Thailand. English Language Teaching, 9(4), 64. https://doi.org/10.5539/elt.v9n4p64 